\title{
SLC27A3 wt Allele
}

National Cancer Institute

\section{Source}

National Cancer Institute. SLC27A3 wt Allele. NCI Thesaurus. Code C106332.

Human SLC27A3 wild-type allele is located in the vicinity of $1 \mathrm{q} 21.3$ and is approximately 6 $\mathrm{kb}$ in length. This allele, which encodes long-chain fatty acid transport protein 3 , is involved in fatty acid-acyl-CoA synthesis. 